\title{
Analysis of Radionuclide Migration through a 200-m Vadose Zone following a 16-year Infiltration Event
}

\author{
A.F.B. Tompson, D.K. Smith, and \\ G.B. Hudson?
}

U.S. Department of Energy

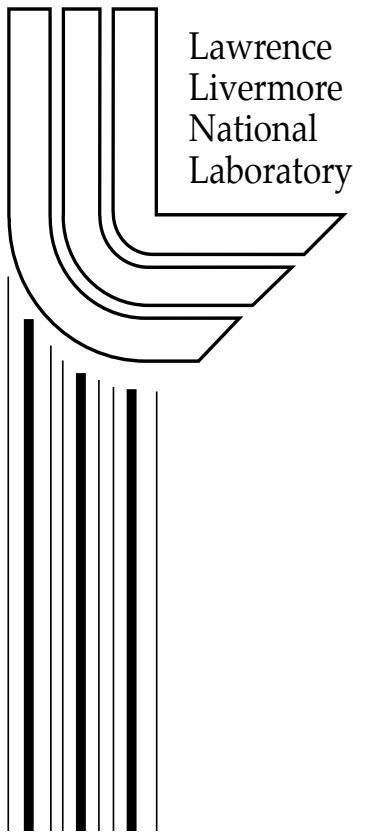

January 31, 2002 


\section{DISCLAIMER}

This document was prepared as an account of work sponsored by an agency of the United States Government. Neither the United States Government nor the University of California nor any of their employees, makes any warranty, express or implied, or assumes any legal liability or responsibility for the accuracy, completeness, or usefulness of any information, apparatus, product, or process disclosed, or represents that its use would not infringe privately owned rights. Reference herein to any specific commercial product, process, or service by trade name, trademark, manufacturer, or otherwise, does not necessarily constitute or imply its endorsement, recommendation, or favoring by the United States Government or the University of California. The views and opinions of authors expressed herein do not necessarily state or reflect those of the United States Government or the University of California, and shall not be used for advertising or product endorsement purposes.

This work was performed under the auspices of the U. S. Department of Energy by the University of California, Lawrence Livermore National Laboratory under Contract No. W-7405-Eng-48.

This report has been reproduced directly from the best available copy.

Available electronically at http://www.doc.gov/bridge

Available for a processing fee to U.S. Department of Energy

And its contractors in paper from

U.S. Department of Energy

Office of Scientific and Technical Information

P.O. Box 62

Oak Ridge, TN 37831-0062

Telephone: (865) 576-8401

Facsimile: (865) 576-5728

E-mail: reports@adonis.osti.gov

Available for the sale to the public from

U.S. Department of Commerce

National Technical Information Service

5285 Port Royal Road

Springfield, VA 22161

Telephone: (800) 553-6847

Facsimile: (703) 605-6900

E-mail: orders@ntis.fedworld.gov

Online ordering: http://www.ntis.gov/ordering.htm

OR

Lawrence Livermore National Laboratory

Technical Information Department's Digital Library

http://www.llnl.gov/tid/Library.html 


\begin{abstract}
The CAMBRIC nuclear test was conducted beneath Frenchman Flat at the Nevada Test Site on May 14, 1965. The nuclear device was emplaced in heterogeneous alluvium, approximately $70 \mathrm{~m}$ beneath the ambient water table, which is itself $220 \mathrm{~m}$ beneath the ground surface. Approximately 10 years later, groundwater adjacent to the test was pumped steadily for 16 years to elicit information on radionuclide migration in the saturated zone. The pumping well effluent - containing mostly soluble radionuclides such as tritium, ${ }^{14} \mathrm{C},{ }^{36} \mathrm{Cl},{ }^{85} \mathrm{Kr},{ }^{129} \mathrm{I}$, and ${ }^{106} \mathrm{Ru}$ - was monitored, discharged to an unlined ditch, and allowed to flow towards Frenchman Lake just over one kilometer away. Water discharged into the ditch infiltrated into the ground during flow along the ditch. This created an unexpected and remarkable second experiment in which the migration of the effluent through the 220 meters of unsaturated media, or "vadose zone", back to the water table, could be studied. In this paper, the pumping and effluent data are being utilized in conjunction with a series of geologic data, new radionuclide measurements, isotopic age-dating estimates, and vadose zone flow and transport models to better understand the movement of radionuclides between the ditch and the water table. Measurements of radionuclide concentrations in water samples produced from a water table monitoring well $100 \mathrm{~m}$ away from the ditch indicate rising levels of tritium since 1993. The detection of tritium in the monitoring well occurs approximately 16 years after its initial discharge into the ditch. Modeling and tritium age dating have suggested 3 to 5 years of this 16-year transit time occurred solely in the vadose zone. They also suggest considerable recirculation of the pumping well discharge back into the original pumping well. Surprisingly, no ${ }^{14} \mathrm{C}$ was observed at the water table, suggesting its preferential retention, possibly due to precipitation or other chemical reaction, during transit to the water table. Overall, the long term nature of the experiment, the variety of chemical measurements and isotopic interpretations, and their incorporation into a unified modeling analysis, have contributed to a unique perspective for interpreting radionuclide migration in the unsaturated zone.
\end{abstract}




\section{Introduction}

The CAMBRIC nuclear test was conducted beneath Frenchman Flat at the Nevada Test Site (NTS) on May 14, 1965. Frenchman Flat is located in Area 5 of the NTS, as shown in Figure 1. The test device was positioned in heterogeneous alluvium, $294 \mathrm{~m}$ beneath the ground surface, and approximately $70 \mathrm{~m}$ beneath the ambient water table. The announced yield of the test was 0.75 kilotons. The explosion created a detonation cavity approximately $22 \mathrm{~m}$ in diameter that as subsequently infilled by collapse rubble and saturated with groundwater (Hoffman et al., 1977).

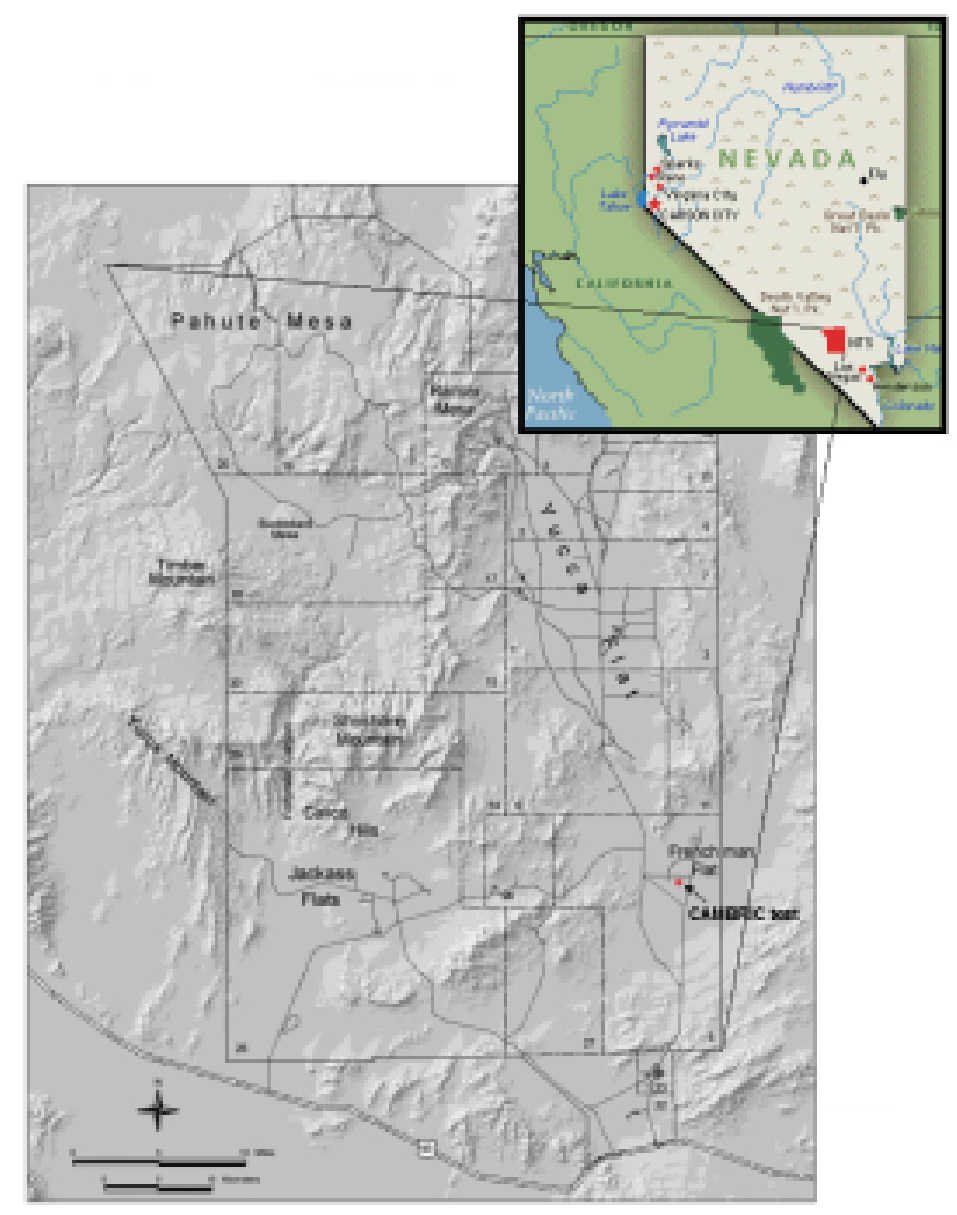

Figure 1: Map of the Nevada Test Site and its location within Nevada. The CAMBRIC test was conducted in Area 5 in Frenchman Flat, in the southeast portion of the NTS.

\subsection{The Pumping Experiment}

Beginning in October, 1975, approximately 10 years after the test, groundwater adjacent to the test cavity was pumped steadily for 16 years, with a few short interruptions, in order to elicit information on test-related radionuclide migration in the saturated zone (Hoffman, et al, 1977; Bryant, 1992). The experiment was motivated by a desire to understand the environmental risks 
posed by radionuclides produced by underground nuclear tests. In Southern Nevada and other continental testing locations in the United States, groundwater resources potentially impacted by underground nuclear testing has profound implications for the availability of domestic and agricultural water supply as well as its eventual discharge into surface water supplies where collateral ecological impacts may occur (USDOE, 1997). In the oceanic testing regions in the South Pacific and Aleutian Islands, additional concerns arise with respect to radionuclide seepage from groundwater into seawater and its subsequent effects on fisheries and related ecologies (e.g., IAEA, 1998).

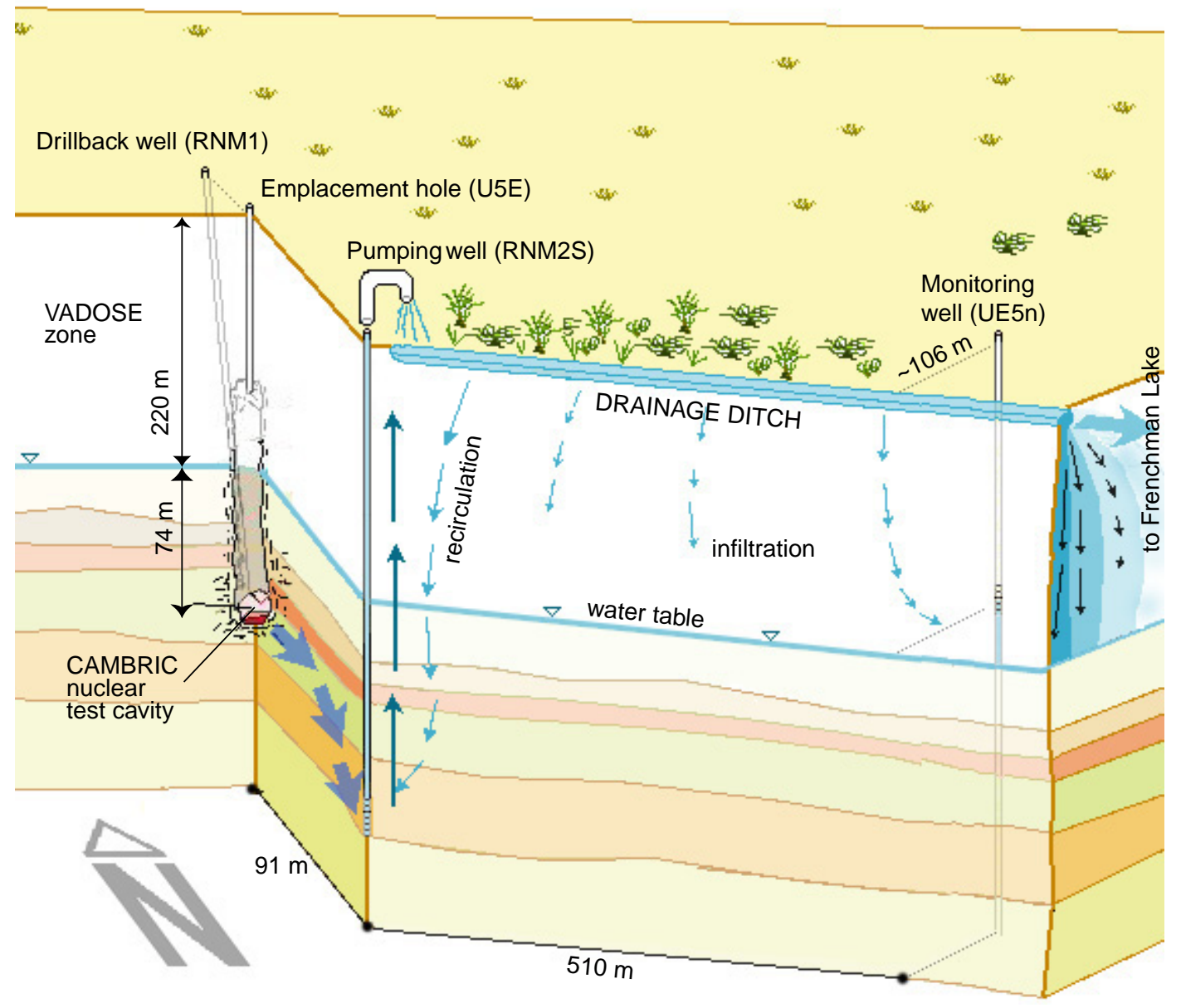

Figure 2: Schematic of the CAMBRIC pumping experiment in Frenchman Flat at the Nevada Test Site, showing the test emplacement hole (U5E), pumping well RNM2S, drainage ditch, and monitoring well UE5n. The test cavity is located some $70 \mathrm{~m}$ beneath the ambient water table, which is itself located approximately $220 \mathrm{~m}$ beneath the ground surface.

As shown in the schematic of Figure 2, the pumping well in this experiment (RNM2S) was located approximately $91 \mathrm{~m}$ south of the CAMBRIC emplacement hole (U5E), and was screened 
over an approximately $25 \mathrm{~m}$ interval between depths of 318 and $343 \mathrm{~m}$, below the test cavity. The pumping well effluent was regularly monitored, discharged to an unlined ditch, and allowed to flow towards the Frenchman Lake playa, just over a mile away (Figures 2-4). Over the duration of the experiment, the effluent produced relatively complete breakthrough profiles of relatively "mobile" radionuclides including tritium (as HTO, Figure 5), ${ }^{36} \mathrm{Cl},{ }^{85} \mathrm{Kr}$, and ${ }^{129} \mathrm{I}$, and sporadic observations of ${ }^{106} \mathrm{Ru}$ and ${ }^{99} \mathrm{Tc}$ arrivals. Relatively "immobile" species such as ${ }^{90} \mathrm{Sr},{ }^{137} \mathrm{Cs}$, and ${ }^{238.239} \mathrm{Pu}$ were looked for but never detected (Bryant, 1992). In addition, a recent measurement of ${ }^{14} \mathrm{C}$ has also been made at the pumping well (see below). Figures 3 and 4 show photographic and map views, respectively, of the region surrounding the experiment, including locations of the CAMBRIC emplacement hole (U5E), the pumping well (RNM2S), and a nearby monitoring well (UE5n). The effluent ditch is shown extending towards Frenchman Lake, and it passes by the nearby DILUTED WATERS (U5B) and WiSHBONE (U5A) underground nuclear tests. In Figure 3, the extensive growth of saltcedar along the ditch, a very invasive nonnative shrub (Brock, 1994), is evident.

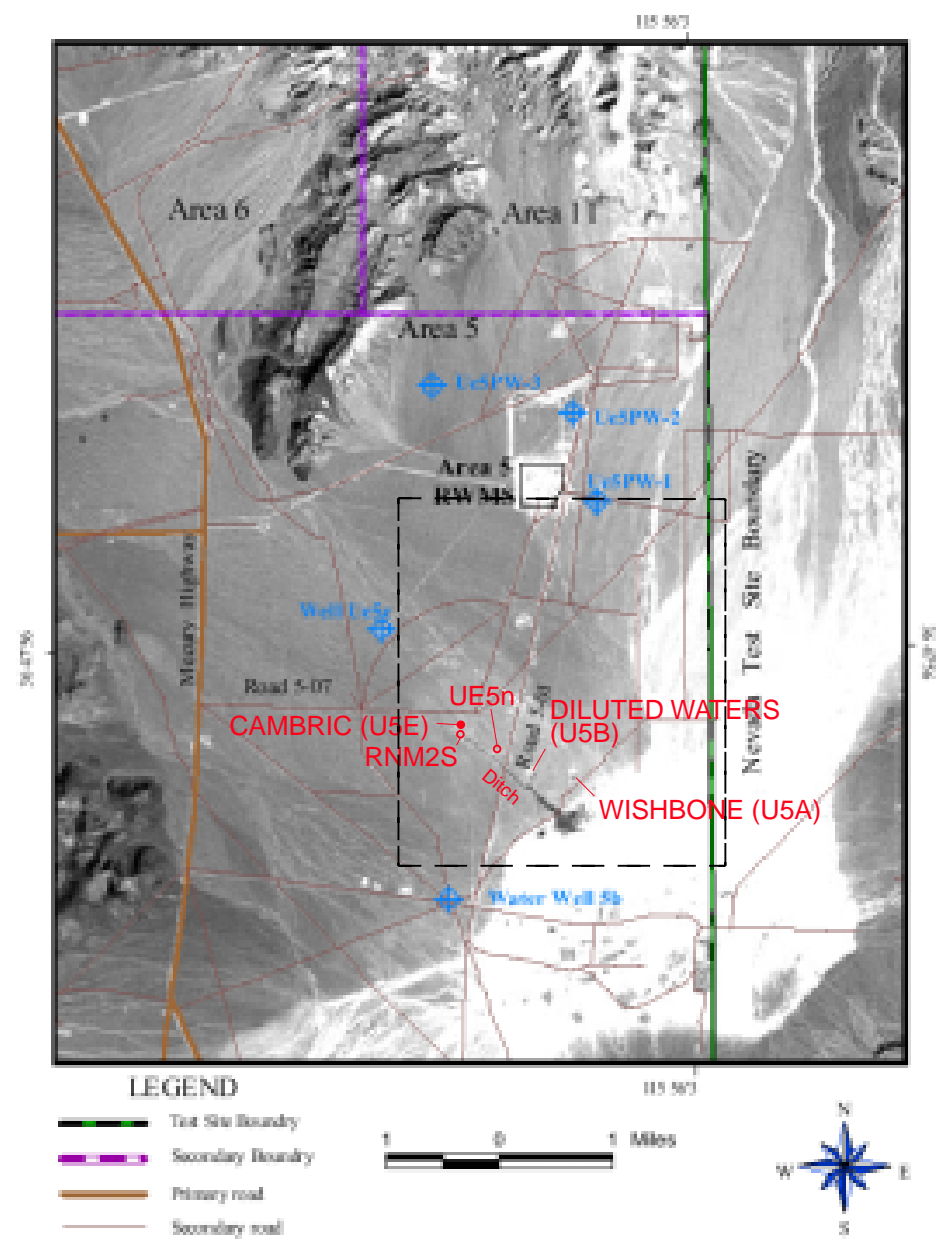

Figure 3: Areal photo of Frenchman Flat showing the CAMBRIC test and wells RNM2S and UE5n. The saltcedar growth surrounding the effluent ditch - which discharges into Frenchman Lake proper - is clearly evident. The locations of the WISHBONE and DILUTED WATERs tests are also shown. The Radioactive Waste Management Site is in the middle of the figure. The map in Figure 4 falls within the indicated rectangular outline. 


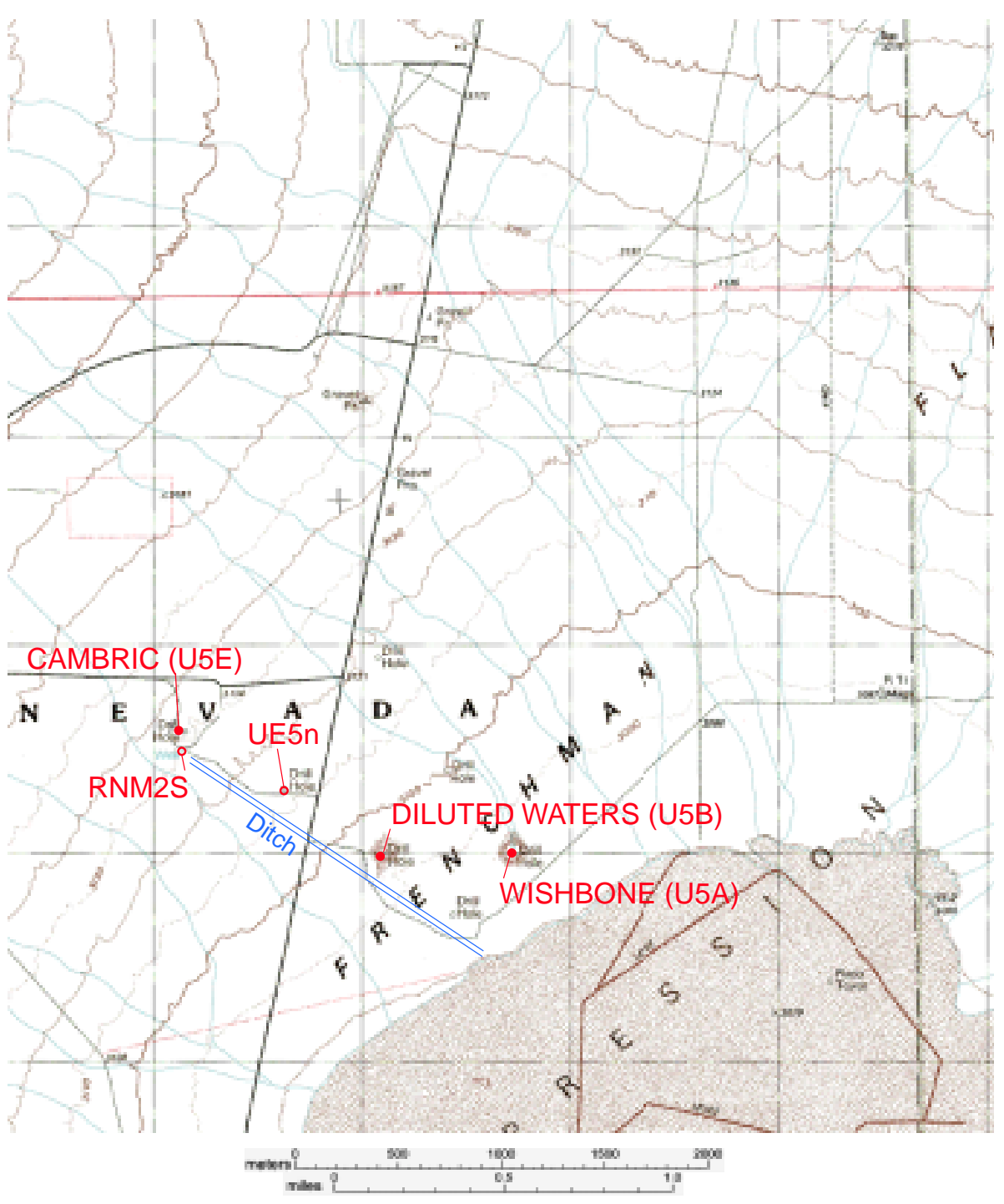

Figure 4: Close-in map of the Frenchman Flat area at the Nevada Test Site showing the CAMBRIC test location and wells RNM2S and UE5n associated with the pumping experiment. The effluent ditch and nearby locations of the WISHBONE and DILUTED WATERS tests are also shown. The Radioactive Waste Management Site is at the top.

The pumping well recovery curve in Figure 3 shows the first arrival of tritium coming after more than two years (900 days) of pumping, and this occurred after the initial pumping rate ( $300 \mathrm{gpm}$, or $1635 \mathrm{~m}^{3} / \mathrm{d}$ ) was doubled (to $600 \mathrm{gpm}$, or $3270 \mathrm{~m}^{3} / \mathrm{d}$ ) after 700 days of pumping. The peak concentration was observed in 1979. In general, the first arrival times of ${ }^{36} \mathrm{Cl}$, ${ }^{85} \mathrm{Kr}$ and ${ }^{129} \mathrm{I}$ were similar to that of tritium. The peak concentration of ${ }^{36} \mathrm{Cl}$ occurred somewhat earlier than that of tritium, while those of ${ }^{85} \mathrm{Kr}$ and ${ }^{129} \mathrm{I}$ were substantially delayed. Measured concentrations of ${ }^{106} \mathrm{Ru}$ and ${ }^{99} \mathrm{Tc}$ were not made at frequent enough intervals to allow similar comparisons. In general, differences in the shapes of these profiles can been attributed to early- 
time phenomenologic (detonation) effects that affect initial radionuclide distributions (Bryant, 1992; Guell, 1997; Tompson et al., 2002), as well as slight differences in the overall mobility of the radionuclides in groundwater. Extensive analyses and studies of the radionuclide migration between the CAMBIRC cavity and the pumping well were conducted both during and after this experiment (e.g., Hoffman, et al., 1977; Burbey and Wheatcraft, 1986; Ogard et al., 1988; Bryant, 1992; Guell, 1997; Tompson et al., 1999a).

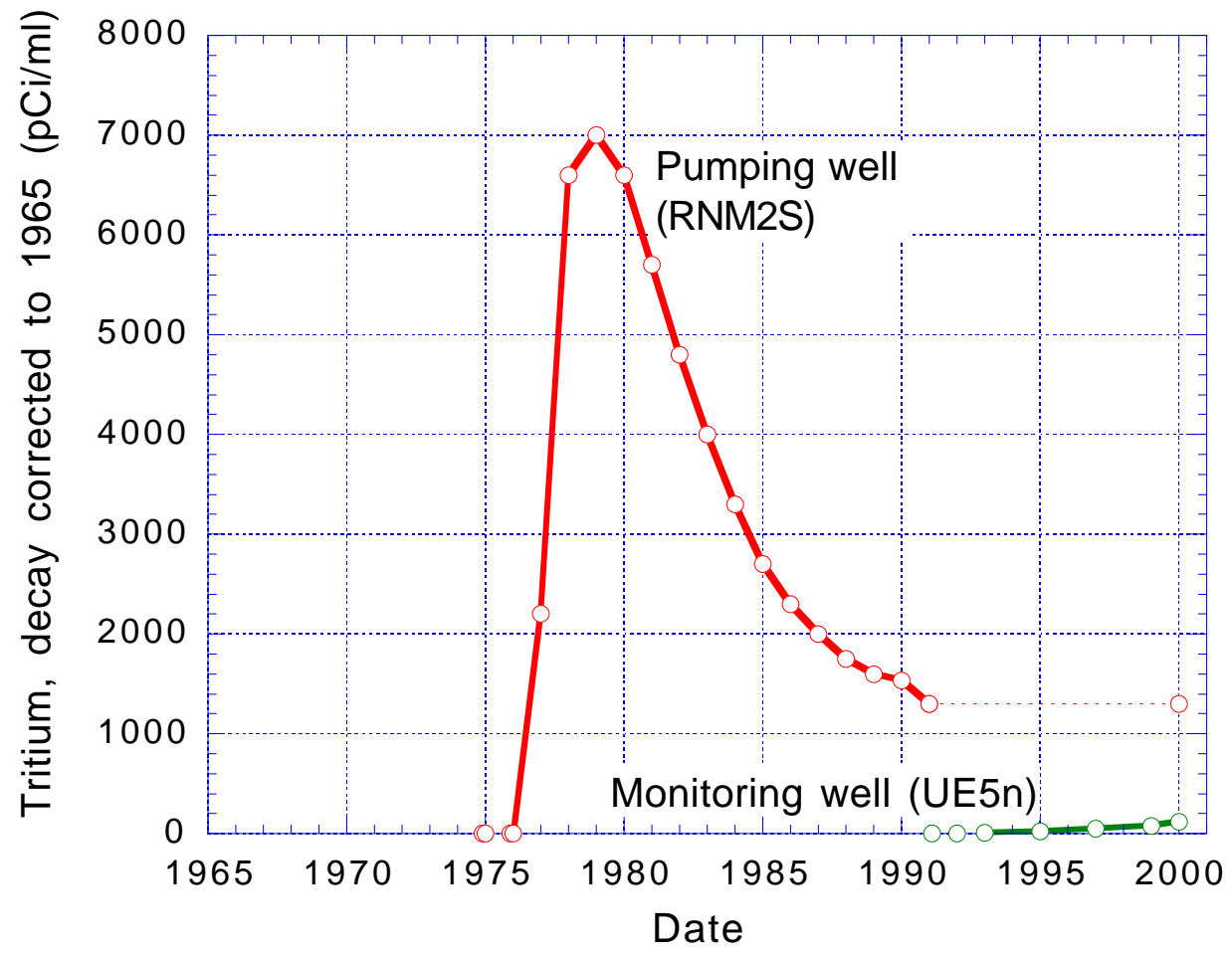

Figure 5: tritium concentrations observed in the pumping well (RNM2S) between the initiation (1975) and cessation of pumping (1991) and in an isolated measurement made in 2000 are shown in red. Rising tritium concentrations in monitoring well UE5n, beginning between 1991 and 1994, are also shown in green.

\subsection{The Infiltration Experiment}

It is notable that there was, initially, very little programmatic interest in the fate of the radionuclides once they were discharged into the ditch. The general perception at the time was that infiltration of the ditch effluent and dissolved radionuclides into the 200 meters of unsaturated alluvium, or "vadose zone", would not be significant enough to warrant any particular scrutiny with regard to recontamination of groundwater. Nevertheless, this concern was challenged in the mid 1980s and early 1990s with a series of soil moisture and water quality measurements in which the infiltration of water and migration of tritium and ${ }^{36} \mathrm{Cl}$ were measured horizontally to about $7 \mathrm{~m}$ and vertically to at least $30 \mathrm{~m}$ beneath and away from the ditch (Buddemeier et al., 1991).

In addition, a series of flume-based measurements of the ditch flow rate between the pumping well and Frenchman Lake indicated that a loss of approximately 175 gpm (or 954 
$\mathrm{m}^{3} / \mathrm{d}$, roughly one third of the upstream flow rate) occurred over an approximately $1000-\mathrm{m}$ distance (Bryant, 1992; Ross and Wheatcraft, 1994). This loss amounts to approximately 0.01 $\mathrm{kg}$-water/s per meter of ditch length (yet was estimated by Ross and Wheatcraft, 1994, to be closer to $0.02 \mathrm{~kg}$-water/s per meter of ditch length). At the time, it had been suggested, based upon these observations, that the travel time for the ditch water (and tritium) to reach the water table might be approximately 9 years (Bryant, 1992).

Moreover, between 1991 and 1994, regular tests of groundwater from a monitoring well sited $106 \mathrm{~m}$ perpendicular to the ditch began to show rising levels of tritium, apparently confirming that infiltrated radionuclides have reached the water table after transiting the roughly $200 \mathrm{~m}$ of unsaturated alluvium (Davisson, et al., 1994). This would thus suggest a 13- to 15year transit time for tritium to move from the ditch to the water table and then to the monitoring well. The measurements were made on bailed samples taken from the 3-m screened interval of the well, centered at a depth of $220 \mathrm{~m}$, just below the water table, and have continued through 1999 (Rose et al., 2002; Figure 5). Although detection of other radionuclides (e.g., ${ }^{14} \mathrm{C},{ }^{36} \mathrm{Cl}$, $\left.{ }^{129} \mathrm{I} /{ }^{127} \mathrm{I}\right)$ was not pursued initially, these mobile radionuclides were subsequently detected in the pumping well and have also reached the water table in the observation period.

\section{Concept for this Study}

The concept for this study grew out of the recognition that the original pumping experiment, the associated ditch infiltration observations, and the ongoing monitoring of water quality in well UE5n created a second, and rather unique, long-term experiment involving vadose zone flow and transport processes. The tritium observations at the monitoring well UE5n, along with the characterized effluent at the pumping well, form the basis for a constrained vadose zone experiment that spans a 25-year time frame between 1975 and 2000.

Contaminant migration in deep unsaturated environments is of considerable concern across much of the US Department of Energy complex, and the scientific and technical challenges for addressing many of these problems are far from being solved (USDOE, 2001). Although vadose zone contamination at the Hanford Reservation in Washington is often cited as a critical example (e.g., http://www.bhi-erc.com/projects/vadose/), the Nevada Test Site and environs offer several additional examples, most notably at the proposed Yucca Mountain nuclear waste repository, adjacent to NTS, as well as on the NTS proper, where approximately $2 / 3$ of the 908 underground nuclear tests were conducted above the water table (USDOE, 1977). Because the real nature and contribution of radionuclides from tests above the water table to groundwater is (understandably) felt by many to be too-difficult a problem to tackle across the entire NTS at the current time, tests conducted above the water table are being considered as saturated for the purposes of estimating radionuclide releases.

Regardless of these issues, the pumping experiment at the CAMBRIC test and the potential for the extracted radionuclides to re-enter groundwater, albeit small in comparison to all NTS tests as a whole, remains as an important part of the CAMBRIC contribution to the hydrologic source term in Frenchman Flat groundwater. This study offers us a basis to more directly quantify these processes, as well, as it will be seen, a chance to re-asses the meaning and importance of the original pumping experiment data. As discussed in the following sections, we are using this study as an opportunity to test the viability of routinely used computer models of 
vadose zone flow and transport for examining such an experiment, especially when coupled with a variety of newly acquired isotopic data from wells RNM2S, RNM1, and UE5n.

\section{Simulation of Infiltration and Tritium Migration}

\subsection{Conceptualization}

The rectangular cross-section shown in Figure 6 was chosen to develop an initial twodimensional model of infiltration and tritium migration between the CAMBRIC ditch and monitoring well UE5n. This model will be used in conjunction with additional chemical isotope data to better analyze the history and nature of infiltration and radionuclide migration over the past 25 years. The model will augment the previous effort of Ross and Wheatcraft (1994) in the sense that the tritium arrival data in UE5n collected since 1994 can now be used for calibration or verification purposes. In addition, several conceptual approximations required to make the previous model converge are no longer required.

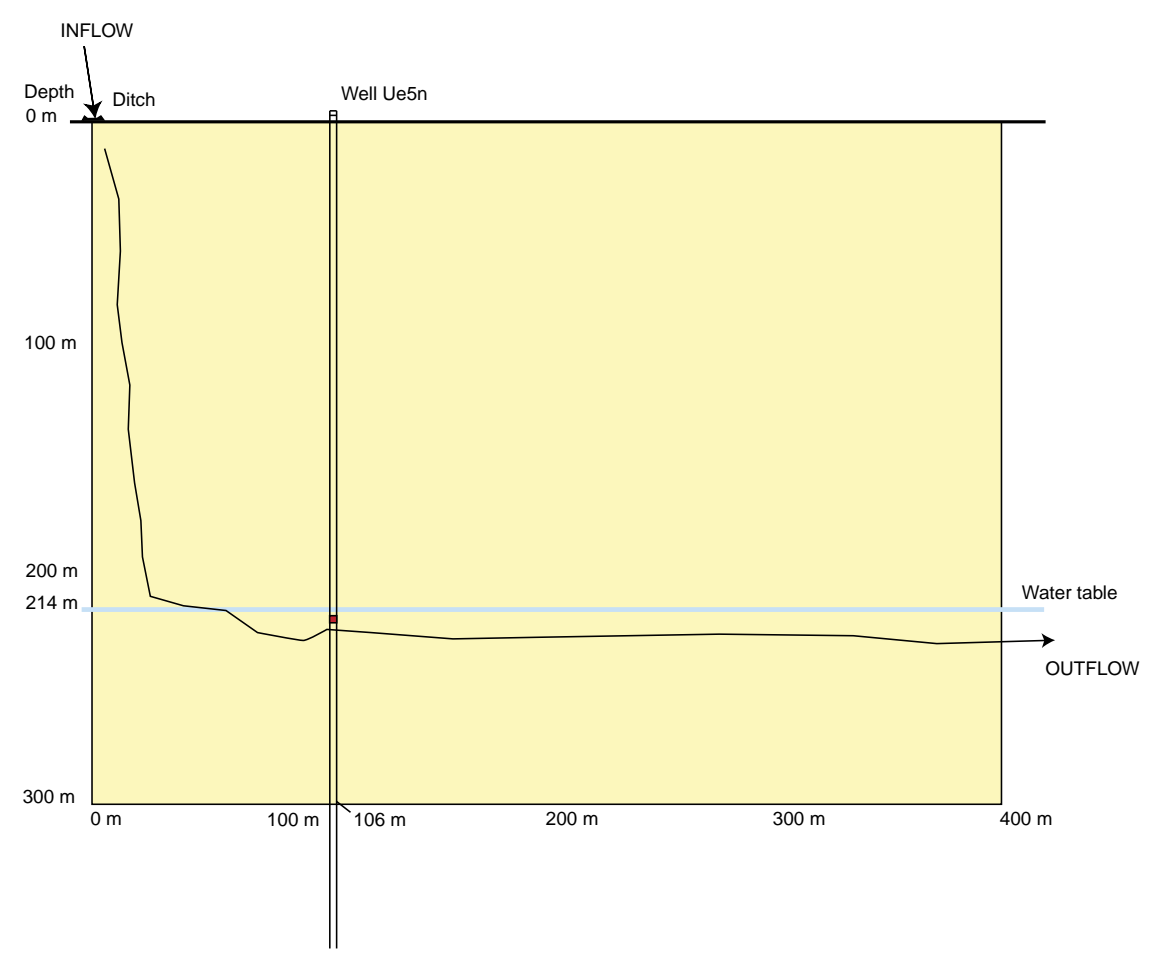

Figure 6: Rectangular cross-sectional modeling domain for the initial two-dimensional model of infiltration and tritium migration between the CAMBRIC ditch and monitoring well UE5n. The well screen is $3 \mathrm{~m}$ long and is centered at a depth of $220 \mathrm{~m}$, just below the water table.

The location of the cross section is considered to be sufficiently far from the pumping well so that the assumption of two-dimensional behavior is adequate. Because the hydraulic gradients in the vicinity of CAMBRIC are close to 0.001 or smaller (Tompson, et al., 1999a), the 
water table has been assumed to be flat in this cross section, allowing a no-flow axis of symmetry underlying the center of the ditch to be chosen. The water table is located at a depth of 214 m, consistent with observations in Well UE5n (Ramspott and McArthur, 1977), and is over $80 \mathrm{~m}$ above the bottom of the domain, located at a depth of $300 \mathrm{~m}$, that is also assumed to be a no flow boundary. The right-hand side of the domain was located some $400 \mathrm{~m}$ away from the ditch centerline in order that the water table can be fixed there, at the same depth of $214 \mathrm{~m}$, as a boundary condition. Water and tritium inflow to the system will be specified over a $1 \mathrm{~m}$ long half-width of the ditch, in the upper left-hand corner of the domain, and allowed to infiltrate towards the water table, accumulate as a mounded groundwater over the initial water table, and eventually exit the domain through the right-hand side boundary, to the extent that the mounding conditions create a gradient that drives groundwater to the right, past the fixed head condition on the boundary. It should also be mentioned that the hydraulic setting in the unsaturated media, above the water table on the right-hand side boundary, is also fixed or maintained in order to yield no-flow conditions.

The USNT module of the NUFT computer code (Nitao, 1999) was used for the current flow and transport simulations. Both liquid and gas phase flow (water and air) were considered, along with appropriate interphase mass transfer processes, and only under isothermal $\left(15^{\circ} \mathrm{C}\right)$ conditions. In general, the inclusion of a dynamic air phase and allowance for interphase mass exchange are pertinent issues, but only of secondary importance in the current work, and so their formal discussion and analysis in the remaining parts of this report will be deferred to a future work.

Frenchman Flat is an intermountain basin formed by Tertiary-age faulting typical of the Basin and Range physiographic province. The model domain is located in a Quaternary/Tertiary alluvium composed of interbedded silts, clays, sands and gravels derived largely from silicic volcanic rocks (tuff and rhyolitic lava). Alteration minerals include clinoptilolite, calcite, smectite, illite, and iron oxide, all of which contribute some sorptive potential to the medium that may inibit the migration of reactive radionuclides. This is most likely why "immobile" species such as ${ }^{90} \mathrm{Sr},{ }^{137} \mathrm{Cs}$, or ${ }^{238.239} \mathrm{Pu}$, present in the test cavity, were never detected at pumping well RNM2S. For simplicity, the geologic system was treated as effectively uniform in terms of its hydraulic properties and characteristics, even though it is clear that small-scale heterogeneity in these properties exists, both within the modeling domain (Ramspott and McArthur, 1977), and elsewhere in Frenchman Flat (REECO, 1994; Istok, et al., 1994; Blout et al., 1995).

\section{2 Mathematical models of flow and transport}

As represented in the NUFT model, the flow of water and air in the system is governed by two sets of mass and momentum balance equations (Nitao, 1999; Bodvarsson et al, 2000), one for each phase. For the water phase, these are given, respectively, by

$$
\frac{\partial\left(\phi S_{w} \rho_{w}\right)}{\partial t}+\nabla \cdot\left(\phi S_{w} \rho_{w} \mathbf{v}_{w}\right)=e_{w a}
$$

and a generalized form of Darcy's law, 


$$
\phi S_{w} \mathbf{v}_{w}=-\mathbf{k} \cdot k_{r w}\left(\nabla p_{w}-\rho_{w} \mathbf{g}\right)
$$

In these expressions, $\mathbf{v}_{w}$ is the macroscopic seepage velocity of water $(\mathrm{L} / \mathrm{T}), S_{w}$ is the fractional saturation of water (dimensionless), and $\phi$ is the porosity (dimensionless) of the medium. On the right hand side of $(2), p_{w}$ is the water phase pressure $\left[\mathrm{M} / \mathrm{LT}^{2}\right], \rho_{w}$ is the water density $\left[\mathrm{M} / \mathrm{L}^{3}\right], \mathbf{g}$ is the gravitational vector $\left[\mathrm{L} / \mathrm{T}^{2}\right]$, and $\mathbf{k}$ and $k_{r w}\left(S_{w}\right)$ are the intrinsic permeability tensor and relative water phase permeability $\left[\mathrm{L}^{2}\right]$ of the medium, respectively. For reference, the intrinsic permeability is related to the saturated hydraulic conductivity via $\mathbf{K}_{s}=\mathbf{k} \rho_{w} g / \mu_{w}[\mathrm{~L} / \mathrm{T}]$ where $\mu_{w}$ is the water viscosity [M/LT] and $g=|\mathbf{g}|$. The quantity $e_{w a}$ in (1) accounts for mass transfer between the air and water phases $\left[\mathrm{M} / \mathrm{L}^{3} \mathrm{~T}\right]$, which for the current simulations, is assumed to be zero. A similar set of equations may be written for the air phase in terms of similar air phase quantities and properties, but will not be considered further here..

The balance of mass for a dilute radionuclide species dissolved in the water phase, such as tritium, is given by

$$
\frac{\partial\left(\phi S_{w} c R\right)}{\partial t}+\nabla \cdot\left(\phi S_{w} \mathbf{v}_{w}\right)+\nabla \cdot \mathbf{J}_{c}=r_{w a}
$$

where $c$ is the species abundance, $\mathbf{J}_{c}$ is a nonadvective (dispersive or diffusive) species flux in the system, $R$ is a chemical retardation parameter, and $r_{w a}$ accounts for species mass transfer between the water and air phases. The species abundance may be expressed in any number of ways, such as an aqueous mole fraction (dimensionless), aqueous mass density $\left(\mathrm{M} / \mathrm{L}^{3}\right)$, or radiochemical activity $\left(\mathrm{Ci} / \mathrm{L}^{3}\right.$ or $\left.\mathrm{Bq} / \mathrm{L}^{3}\right)$. In the current application, $r_{w a}$ is assumed to be zero and $\mathbf{J}_{c}$ is used to only represent diffusive flux only, with an effective diffusion coefficient of $10^{-9} \mathrm{~m}^{2} / \mathrm{s}$. For nonreactive species, $R=1$. In addition, as above, migration in the air phase will not be considered further here.

\subsection{Constitutive relationships and flow parameters for the water phase}

In general, if the air phase is assumed static at a fixed atmospheric pressure $p_{a}$, then the balances (1) and (2) will involve two equations expressed in terms of three unknowns ( $\mathbf{v}_{w}, S_{w}$, and $\left.p_{w}\right)$. The so-called water retention, or capillary pressure constitutive function

$$
p_{a}-p_{w}=P_{c}=P_{c}\left(S_{w}\right)
$$

is typically used to close the series of equations. In the current model, the simple Van Genuchten relationship (Nitao, 1999; Bodvarsson, et al., 2000) will be used to parameterize this function, namely,

$$
P_{c}\left(S_{w}\right)=\frac{\rho_{w} g}{\alpha} \cdot\left(\left(\frac{S_{w}-S_{w r}}{1-S_{w r}}\right)^{-1 / m}-1\right)^{1-m}
$$


where $\alpha$ and $m$ are considered measurable soil parameters and $S_{w r}$ is the residual water saturation, used to define the endpoint saturation in a drainage test, which is also a measurable soil parameter. Occasionally, (5a) is expressed in a shorthand notation as

$$
P_{c}\left(S_{w}\right)=\frac{1}{\alpha^{*}} \cdot\left(S_{w}^{*-1 / m}-1\right)^{1-m}
$$

where

$$
S_{w}^{*}=\frac{S_{w}-S_{w r}}{1-S_{w r}}
$$

and

$$
\alpha^{*}=\alpha / \rho_{w} g
$$

In (2), the relative permeability is also considered to be saturation dependent, and is modeled here in terms of a complementary Van Genuchten relationship (Nitao, 1999; Bodvarsson, et al., 2000),

$$
k_{r w}=\left(S_{w}^{*}\right)^{1 / 2}\left(1-\left(1-\left(S_{w}^{*}\right)^{1 / m}\right)^{m}\right)^{2}
$$

Thus, in addition to boundary and initial condition information, the parametric medium properties required for the flow model include the intrinsic permeability tensor, $\mathbf{k}$, the residual saturation, $S_{w r}$, and the soil retention parameters, $\alpha$ and $m$.

\subsection{Initial model development}

The model domain in Figure 6 was discretized into an orthogonal mesh of 81 by 136 grid blocks, with irregularly-sized cell sizes ranging from 0.5 by $0.5 \mathrm{~m}$ underneath the ditch to 16 by $8 \mathrm{~m}$ near the bottom, right-hand side of the domain. The $\mathrm{x}-\mathrm{z}$ coordinate system is anchored at the ditch centerline, with the $x$-axis increasing positively to the right in Figure 6 , and the $z$-axis increasing positively down. The finest resolution of the grid is concentrated on the left-hand side of the domain, between the ditch centerline and monitoring well UE5n. The upper row of blocks, with the exception of the left-most two, are treated as a dry $\left(S_{w}=0\right)$ atmospheric interface with a porosity of 0.99 . Recharge from precipitation was not considered in this model. The left-most two blocks in the upper row, spanning a horizontal distance of $1 \mathrm{~m}$ (with an $0.5 \mathrm{~m}$ depth), represent one-half of the ditch width and were treated as ditch recharge cells.

Fixed pressure conditions consistent with an approximate water depth of $2.5 \mathrm{~cm}$ (or about 1 inch) in the ditch were specified in the two ditch blocks as a means to force water to infiltrate 
into the system. Computed water fluxes across this interface were monitored for comparison with the previously estimated influx rate, as a means to calibrate values assigned to the medium permeability. This approach did not discriminate or allow for the lower ditch flow rate in the first 700 days of pumping to be fully represented. Alternatively, the estimated influx rate could have been assigned directly as an inflow condition, although some adjustment would have to be made for the lower initial pumping rate, and the transient variation of the infiltration that would occur as the upper portions of the domain become increasingly saturated would not be reflected in this approach. Tritium migration was addressed by setting the its concentration in the ditch inflow to match the elution profile shown in Figure 5, but only though 1991, after which it was set to zero. Over the 16 years of pumping, a significant stand of saltcedar grew along the banks of the ditch (Figure 3). Although this shrub is known to be invasive and consume a large amount of water (e.g., Gay et al., 1976; Anderson, 1977), evapotranspirative losses of moisture in the vicinity of the ditch, due to uptake in salt cedar, were not addressed in the current model.

Because the geologic system is being treated as homogeneous, fixed parametric properties will be specified at all locations in the domain, although the intrinsic permeability will be considered as an anisotropic quantity with principal axes aligned with the $x$ and $z$ model axes. This approach will necessarily ignore small-scale infiltration and transport effects associated with fine-scale heterogeneity. It assumes that the traditional balance equations and constitutive relationships in (1-6) are valid at the larger field scale considered here (e.g., Mantoglou and Gelhar, 1987), despite the fact that most of the parametric measurements (see below) were made on smaller scale medium samples.

Table 1. Measurements of soil retention parameters and residual saturations in nearsurface soils close to monitoring well UE5n (Ross and Wheatcraft, 1994). Shaded data correspond to parameters used in Ross and Wheatcraft (1994) model.

\begin{tabular}{cccccc}
\hline \hline Depth (m) & $\alpha\left(\mathrm{cm}^{-1}\right)$ & $\alpha *\left(\mathrm{~Pa}^{-1}\right)$ & $\mathrm{m}$ & $\begin{array}{c}\text { Residual } \\
\text { moisture } \\
\text { content, } \\
\phi S_{w r}\end{array}$ & $\begin{array}{c}S_{w r}, \\
\text { assuming } \\
\phi=0.33\end{array}$ \\
\hline 0.45 & 0.0181 & $1.85 \mathrm{e}-4$ & 0.58 & 0.094 & 0.28 \\
0.75 & 0.0280 & $2.86 \mathrm{e}-4$ & 0.36 & 0.057 & 0.17 \\
1.05 & 0.0840 & $8.57 \mathrm{e}-4$ & 0.23 & 0.018 & 0.055 \\
1.35 & 0.2770 & $2.83 \mathrm{e}-3$ & 0.34 & 0.083 & 0.25 \\
1.65 & 0.3250 & $3.32 \mathrm{e}-3$ & 0.39 & 0.099 & 0.30 \\
1.95 & 0.4340 & $4.43 \mathrm{e}-3$ & 0.17 & 0.012 & 0.036 \\
\hline Mean & 0.1944 & $1.98 \mathrm{e}-3$ & 0.35 & 0.061 & 0.18 \\
\hline \hline
\end{tabular}

\subsection{Field data}

The current computer simulations of the infiltration process were developed in terms of available - yet sparse - characteristic data for the local geological media, in addition to the 
related observational data about ditch flows and measured radionuclide concentrations in the monitoring well UE5n. Table 1 summarizes a series of soil retention parameter and residual saturation measurements made in near- surface soils close to monitoring well UE5n (Ross and Wheatcraft, 1994). Fluctuation of these parameters is obvious and is due, in part, to natural variability and heterogeneity. Although only one value of $\alpha$ and $m$ was used in the Ross and Wheatcraft simulations (shaded in table), apparently none of the residual water saturations were used. Residual values of $S_{w r}$ as high as 0.60 had to be assigned in the model, apparently for (numerical) model convergence purposes.

Table 2 summarizes a series of measurements or estimates of the vertical saturated hydraulic conductivity in the vicinity of CAMBRIC, as developed by Ross and Wheatcraft (1994) and summarized by Tompson et al. (1999a). The Ross and Wheatcraft data were obtained from near-surface permeameter and instantaneous profile measurements as well as simple observations of ditch transmission losses. In fact, a value obtained in this latter case was the value selected for use in their model. The range of values summarized from the Tompson et al. (1999a) report represent a range of values used for saturated zone modeling of radionuclide migration between the CAMBRIC cavity and well RNM2S. These were culled and assembled from data and model simulation parameters in the work of Hoffman, et al. (1977); Daniels (1982), LATA (1982), and Burbey and Wheatcraft (1986).

Table 2. Summary of vertical hydraulic conductivity data detailed by Ross and Wheatcraft (1994) from near-surface permeameter measurements and related canal transmission loss estimates. Shaded entry corresponds to the (initially isotropic) value used in their model. Range of data used in saturated zone models, as summarized by Tompson et al (1999a) is also shown.

\begin{tabular}{ccc}
\hline \hline Source & $\begin{array}{c}\text { Saturated } \\
\text { hydraulic } \\
\text { conductivity, } \\
K_{z}(\mathrm{~m} / \text { day) }\end{array}$ & $\begin{array}{c}\text { Saturated } \\
\text { permeability, } \\
k_{z}\left(\mathrm{~m}^{2}\right)\end{array}$ \\
\hline Permeameter Data & 1.96 & $2.64 \mathrm{e}-12$ \\
& 0.0235 & $3.16 \mathrm{e}-14$ \\
& 0.0942 & $1.27 \mathrm{e}-13$ \\
& 0.0324 & $4.36 \mathrm{e}-14$ \\
Canal Transmission Loss & 0.0219 & $2.95 \mathrm{e}-14$ \\
Instantaneous Profile & 0.0251 & $3.38 \mathrm{e}-14$ \\
Saturated zone models & 0.543 & $7.30 \mathrm{e}-13$ \\
(e.g. Tompson et al, 1999a) & 1.66 & $2.23 \mathrm{e}-12$ \\
\hline \hline
\end{tabular}


The simulations of Ross and Wheatcraft (1994) initially regarded the hydraulic conductivity as an isotropic quantity, but later utilized horizontal to vertical anisotropy $\operatorname{ratios}\left(K_{x} / K_{z}\right)$ in the range of 5 to 10 in order to reduce a significant groundwater mounding effect. Interestingly, this anisotropy was only specified in the lower parts of their domain near the water table despite the fact that anisotropy in the hydraulic conductivity or permeability is typically used in a uniform sense to represent the effects of small-scale stratification and heterogeneity in the geologic medium. Many of the saturated zone models in the CAMBRIC vicinity have used anisotropy values in the range of 5 to 10 (Daniels, 1982; LATA, 1982; and Burbey and Wheatcraft, 1986).

Water level depths measured in well UE5n between December 1976 (just over a year after ditch flows were initiated) and August 1997 are shown in Figure 7. Although this data begins about a year after the initiation of pumping, there seems to be no apparent mounding effect at the well. Although there appears to be a subtle drop in the water level in 1991, it is not clear whether this is related to the cessation of the ditch flows. Notably, the fluctuations in depth to water never exceed 1.5 meters over the entire 20 -year plus record.

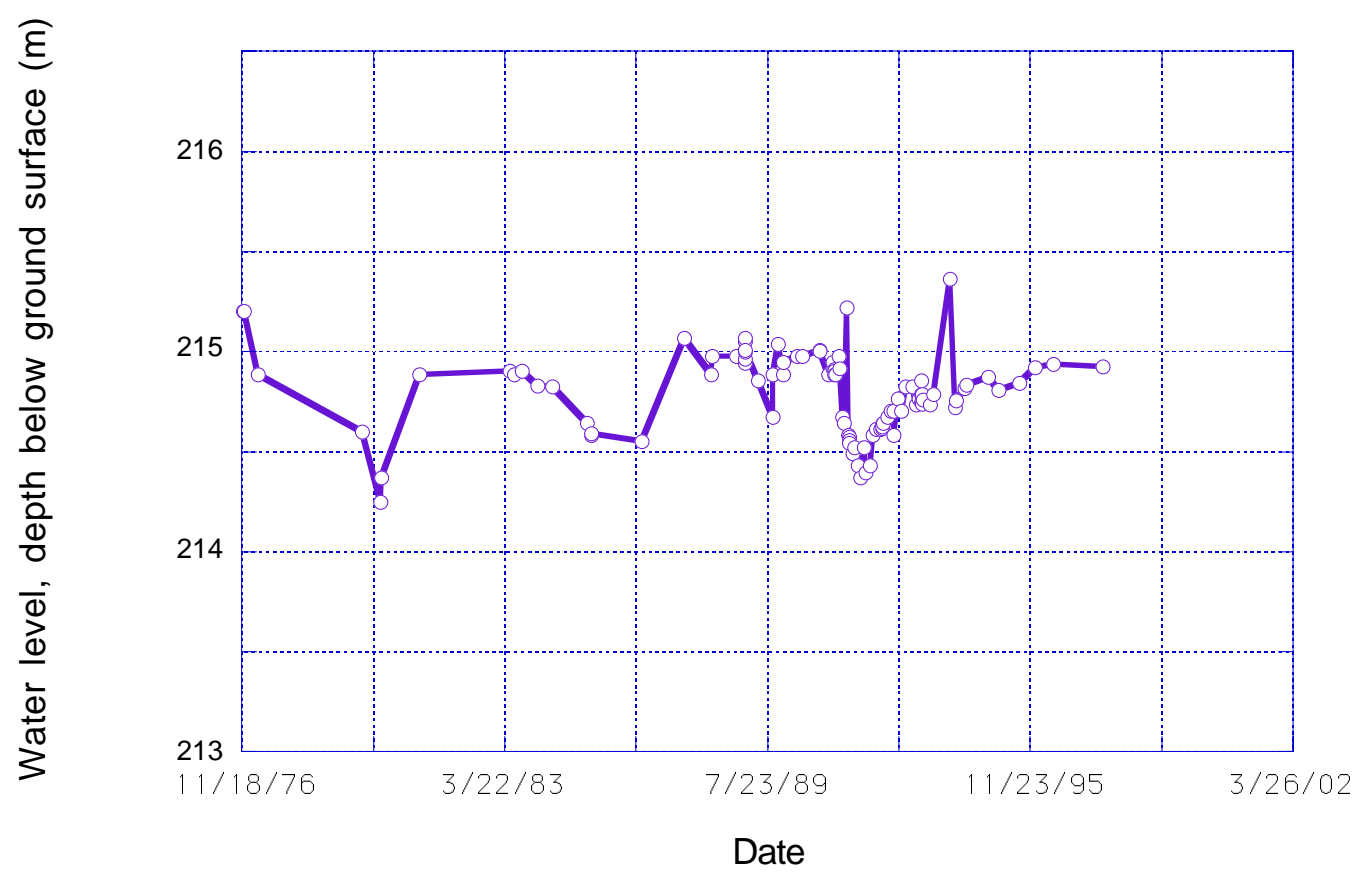

Figure 7. Depth to water (m) measured in well UE5n from December 1976 to August 1997 (data courtesy K. Rehfeldt, Geotrans Inc., Las Vegas, NV).

Table 3 summarizes another set of hydraulic conductivity and soil retention data, as measured from a series of geologic extracted from the so-called Area 5 Science Boreholes (Blout, 1995). These boreholes are located on the Radioactive Waste Management Site in northern Frenchman Flat (Figures 3 and 4) and individually extend approximately 100 meters into unsaturated alluvium. The data shown in Table 3 represent mean values of a much larger set of data and are included here as representative alluvium data for another location in Frenchman Flat and for simple comparison with the data in Tables 1 and 2. The data from the science boreholes much more clearly document the natural variability and heterogeneity of the 
Frenchman Flat alluvium. In general, the data in the three tables compare reasonably well. Although the permeabilities measured in the science boreholes tend to be larger, on average, than those determined in the permeameter tests (Table 2), this may be due, in part, to differences in experimental techniques, or to generally lower surface permeabilities at the surface where the data in Table 2 were measured.

Table 3. Summary of averaged hydraulic conductivity and soil retention data taken from samples extracted from the Science Boreholes in Frenchman Flat (Blout et al., 1995).

\begin{tabular}{ccccccccc}
\hline \hline Borehole & $\begin{array}{c}\text { Mean } \\
\text { saturated } \\
\text { hydraulic } \\
\text { conductivity, } \\
K_{z}(\mathrm{~cm} / \mathrm{s})\end{array}$ & $\begin{array}{c}\text { Mean } \\
\text { saturated } \\
\text { permeability, } \\
k_{z}\left(\mathrm{~m}^{2}\right)\end{array}$ & $\begin{array}{c}\text { Mean } \\
\alpha\left(\mathrm{cm}^{-1}\right)\end{array}$ & $\begin{array}{c}\text { Mean } \\
\alpha *\left(\mathrm{~Pa}^{-1}\right)\end{array}$ & $\begin{array}{c}\text { Mean } \\
\mathrm{m}\end{array}$ & $\begin{array}{c}\text { Residual } \\
\text { moisture } \\
\text { content, } \\
\phi S_{w r}\end{array}$ & $\begin{array}{c}\text { Mean } \\
\text { saturated } \\
\text { porosity, } \\
\phi\end{array}$ & $\begin{array}{c}\text { Mean } \\
S_{w r}\end{array}$ \\
\hline $\mathrm{AP}-1$ & 0.0025 & $2.91 \mathrm{e}-12$ & 0.082 & $8.37 \mathrm{e}-4$ & 0.38 & 0.068 & 0.35 & 0.19 \\
$\mathrm{AP}-2$ & 0.0024 & $2.79 \mathrm{e}-12$ & 0.060 & $6.12 \mathrm{e}-4$ & 0.39 & 0.060 & 0.34 & 0.18 \\
$\mathrm{RP}-1$ & 0.0011 & $1.28 \mathrm{e}-12$ & 0.069 & $7.04 \mathrm{e}-4$ & 0.40 & 0.076 & 0.37 & 0.21 \\
$\mathrm{RP}-2$ & 0.0009 & $1.05 \mathrm{e}-12$ & 0.147 & $1.50 \mathrm{e}-3$ & 0.29 & 0.064 & 0.35 & 0.18 \\
$\mathrm{NN}-1$ & 0.0033 & $3.84 \mathrm{e}-12$ & 0.239 & $2.44 \mathrm{e}-3$ & 0.20 & 0.006 & 0.38 & 0.016 \\
$\mathrm{NW}-1$ & 0.0023 & $2.67 \mathrm{e}-12$ & 0.252 & $2.57 \mathrm{e}-3$ & 0.19 & 0.003 & 0.36 & 0.0083 \\
\hline \hline
\end{tabular}

\subsection{Current Results}

The data presented in Tables 1-3 were used to guide the development and approximate calibration of the current two-dimensional flow and transport model simulations. Parameters used in several representative simulations are shown in Table 4. Factors considered in this process involved:

- Setting permeability values within the measured ranges in Tables 2 and 3 while using realistic anisotropy factors within to the 2 to 10 range, so that the estimated infiltration rates underneath the ditch could be approximately matched while avoiding the creation of any significant mounding effect at the water table;

- Setting realistic values of $\alpha^{*}$ and $m$ within the observed ranges in Tables 1 and 3, while seeking to understand and recognize their sensitive impacts on imbibition rates and the degree to which the simulated recovery curves in UE5n are affected;

- Fixing the porosity and background residual water saturation to uniform values of 0.33 and 0.20 , respectively;

- Fixing the effective diffusivity of tritium at $10^{-9} \mathrm{~m}^{2} / \mathrm{s}$, while neglecting dispersion fluxes;

- Fixing the water level at a depth of $214 \mathrm{~m}$ along the right-hand side of the domain, $400 \mathrm{~m}$ away from the ditch centerline; and 
- Recognition that a completely homogeneous model, and one in which recharge and evapotranspiration are excluded, may not be wholly sufficient to match every observation at the site.

Figure 8 shows saturation profiles at four different times since the initiation of pumping for simulation $3.2 \mathrm{~g}$ (Table 4). Here we see a moisture plume sinking from the ditch and reaching the water table between 3 and 5 years. At $t=25$ years, corresponding to the year 2000,9 years after the cessation of pumping, we still see a significant moisture plume in the system. Complete drainage back to ambient (residual) conditions will take a long time, and, in the model, is ultimately controlled by the permeability and soil moisture retention parameters. In Figure 9, the computed ditch inflow rate for this problem is shown to vary between the estimates ( 0.01 to $0.02 \mathrm{~kg}$-water/s per meter length of ditch) inferred from the flume-based flow measurements. The decrease in inflow rate overtime is due to the increasing saturation conditions beneath the ditch, which will tend to limit or otherwise throttle inflows as the moisture plume expands.

The distribution of tritium concentration for this problem is also shown in Figure 8. Here, we see tritium also reaching the ditch at about $t=5$ years, which, when the 2-year delay in its release into the ditch flow is taken into account, suggests a slightly shorter travel time of about 3 years to the groundwater in the "established" moisture plume. After reaching the water table, the tritium is shown to migrate toward the UE5n monitoring well. The average concentration in the well screen (near the water table), as computed by the model is shown in Figure 10 and compared with the historic measured data.

Table 4. Summary of hydraulic conductivity and soil retention data used in the representative simulations of this report. Shaded rows correspond to plume images in Figures 8 and 11.

\begin{tabular}{cccccccc}
\hline \hline Run & $\begin{array}{c}\text { Saturated } \\
\text { vertical } \\
\text { permeability, } \\
k_{z}\left(\mathrm{~m}^{2}\right)\end{array}$ & $\begin{array}{c}\text { Saturated } \\
\text { horizontal } \\
\text { permeability, } \\
k_{x}\left(\mathrm{~m}^{2}\right)\end{array}$ & $\begin{array}{c}\text { Anisotropy } \\
\text { ratio, } \\
k_{x} / k_{z}\end{array}$ & $\alpha *\left(\mathrm{~Pa}^{-1}\right)$ & $\mathrm{m}$ & $\begin{array}{c}\text { Porosity, } \\
\phi\end{array}$ & $\begin{array}{c}\text { Residual } \\
\text { water } \\
\text { content, } \\
S_{w r}\end{array}$ \\
\hline $3.2 \mathrm{c}$ & $6.099 \mathrm{e}-13$ & $4.269 . \mathrm{e}-12$ & 7 & $2.04 \mathrm{e}-3$ & 0.25 & 0.33 & 0.20 \\
$3.2 \mathrm{~d}$ & $6.099 \mathrm{e}-13$ & $4.269 . \mathrm{e}-12$ & 7 & $1.02 \mathrm{e}-3$ & 0.35 & 0.33 & 0.20 \\
$3.2 \mathrm{~g}$ & $6.099 \mathrm{e}-13$ & $4.269 . \mathrm{e}-12$ & 7 & $2.04 \mathrm{e}-3$ & 0.24 & 0.33 & 0.20 \\
$3.2 \mathrm{u}$ & $6.099 \mathrm{e}-13$ & $4.269 . \mathrm{e}-12$ & 7 & $1.02 \mathrm{e}-3$ & 0.399 & 0.33 & 0.20 \\
$8 \mathrm{e}$ & $4.066 \mathrm{e}-13$ & $2.846 \mathrm{e}-12$ & 7 & $1.90 \mathrm{e}-3$ & 0.25 & 0.33 & 0.20 \\
\hline \hline
\end{tabular}


3 years

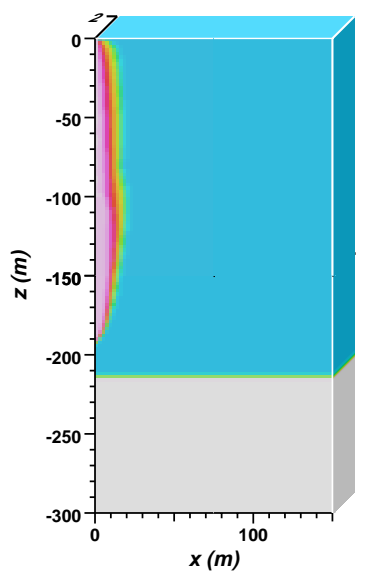

3 years

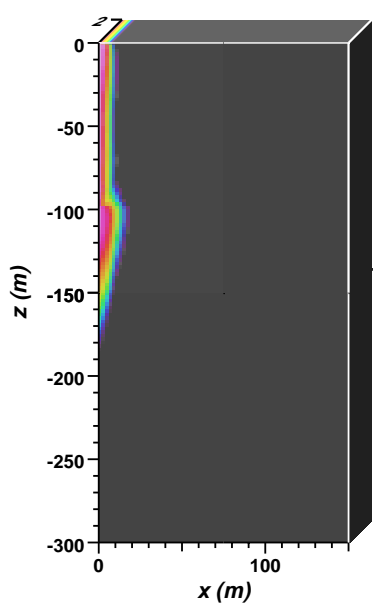

5 years
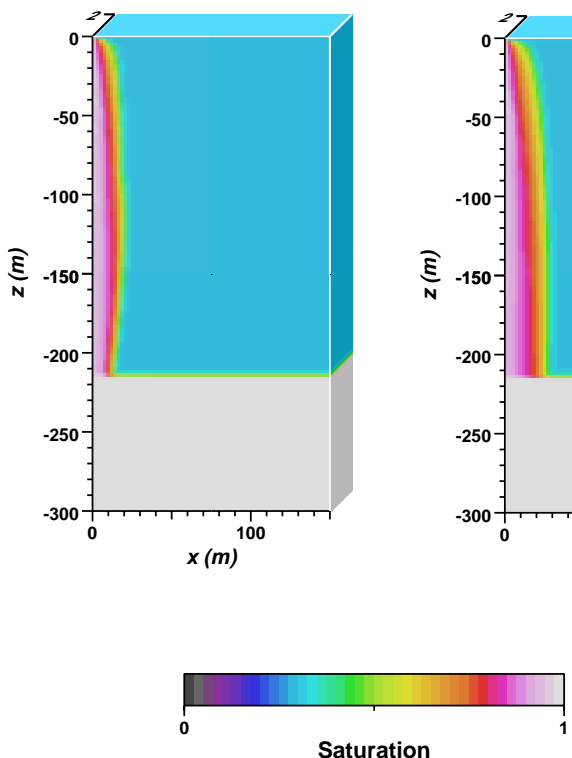

Run 3.2g

5 years

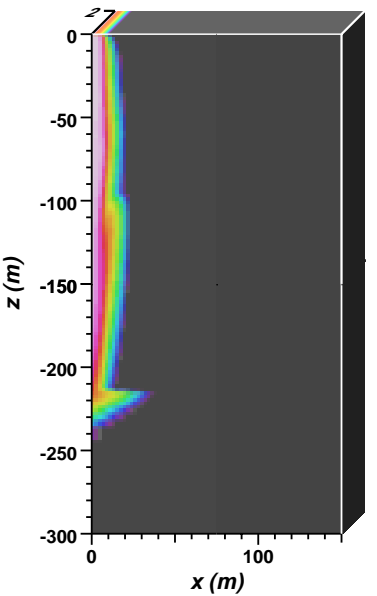

15 years
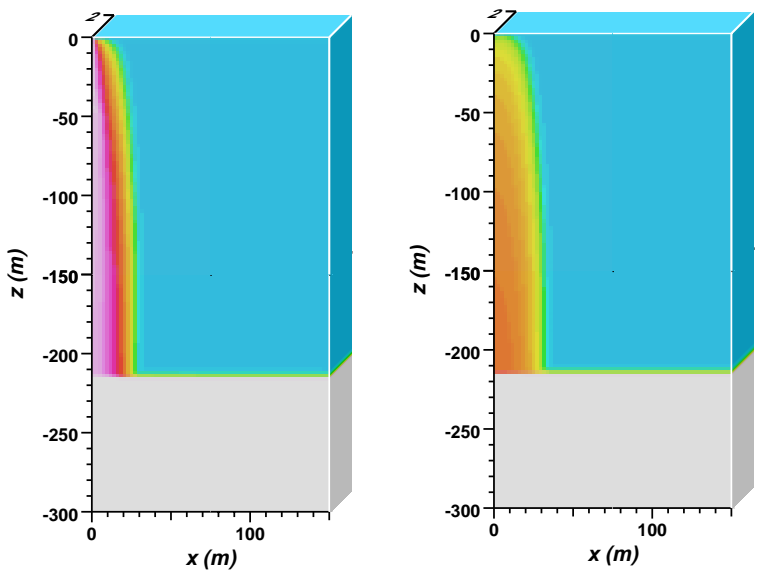

15 years
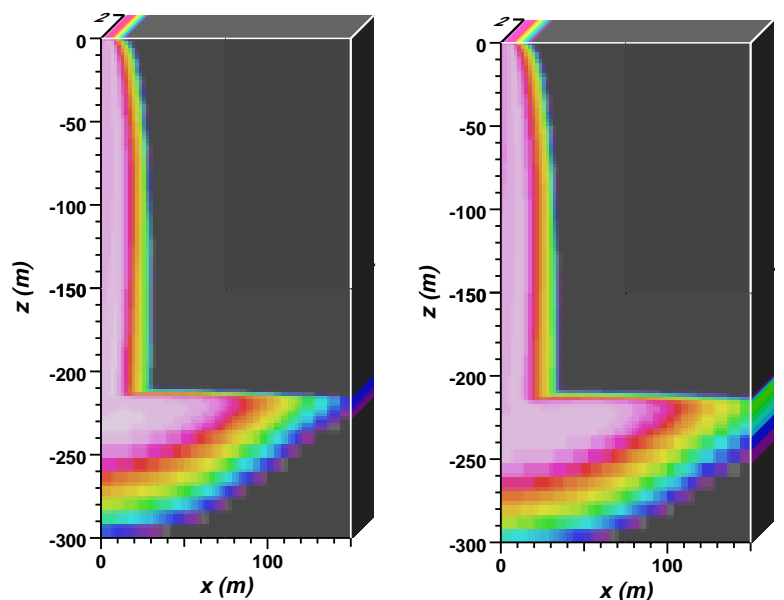

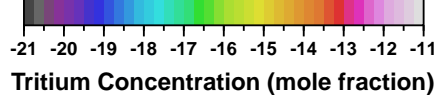

Run 3.2g

Figure 8. Saturation (above) and tritium concentration (below) profiles predicted from simulation 3.2g (Table 4). Dates refer, approximately, to time after initiation of pumping. Moisture arrival at water table is predicted between 3 and 5 years. Monitoring Well UE5n is located at $x=106 \mathrm{~m}$. 


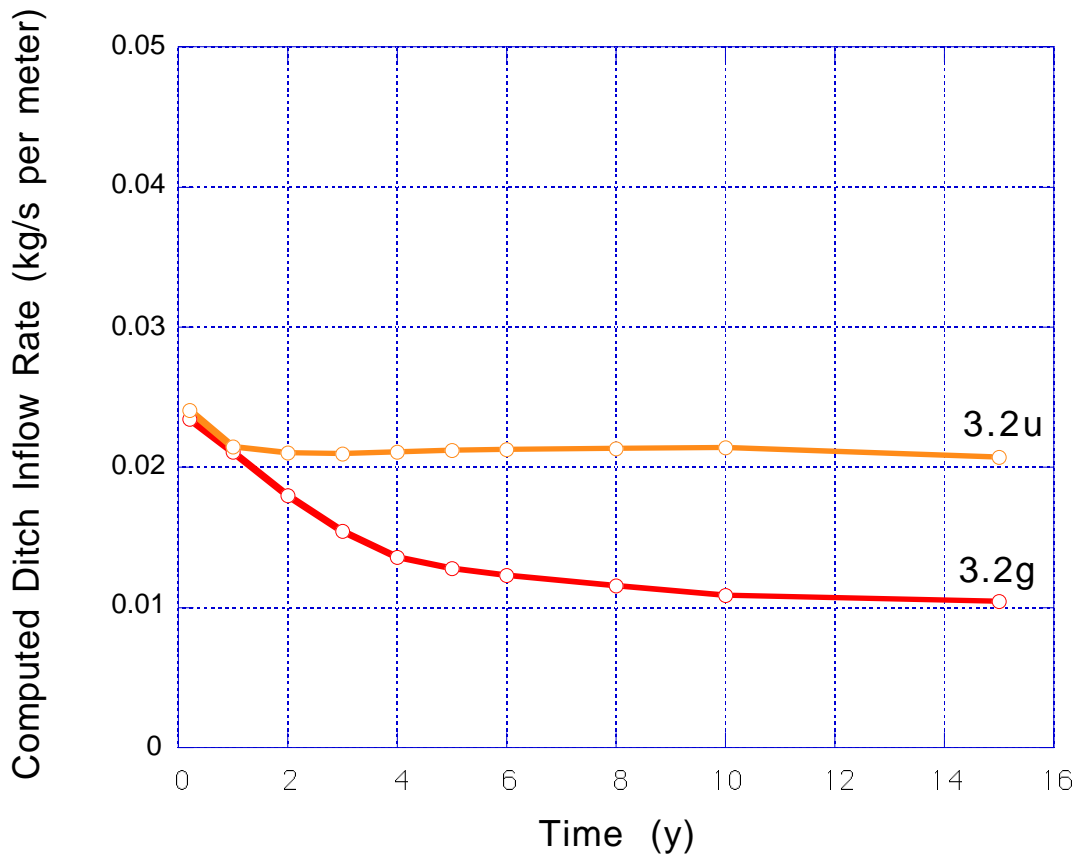

Figure 9. Computed ditch inflow rate as a function of time for two particular simulations. The rates compare favorably with the estimates $(0.01$ to $0.02 \mathrm{~kg}$-water/s per meter length of ditch) inferred from the flume-based flow measurements.
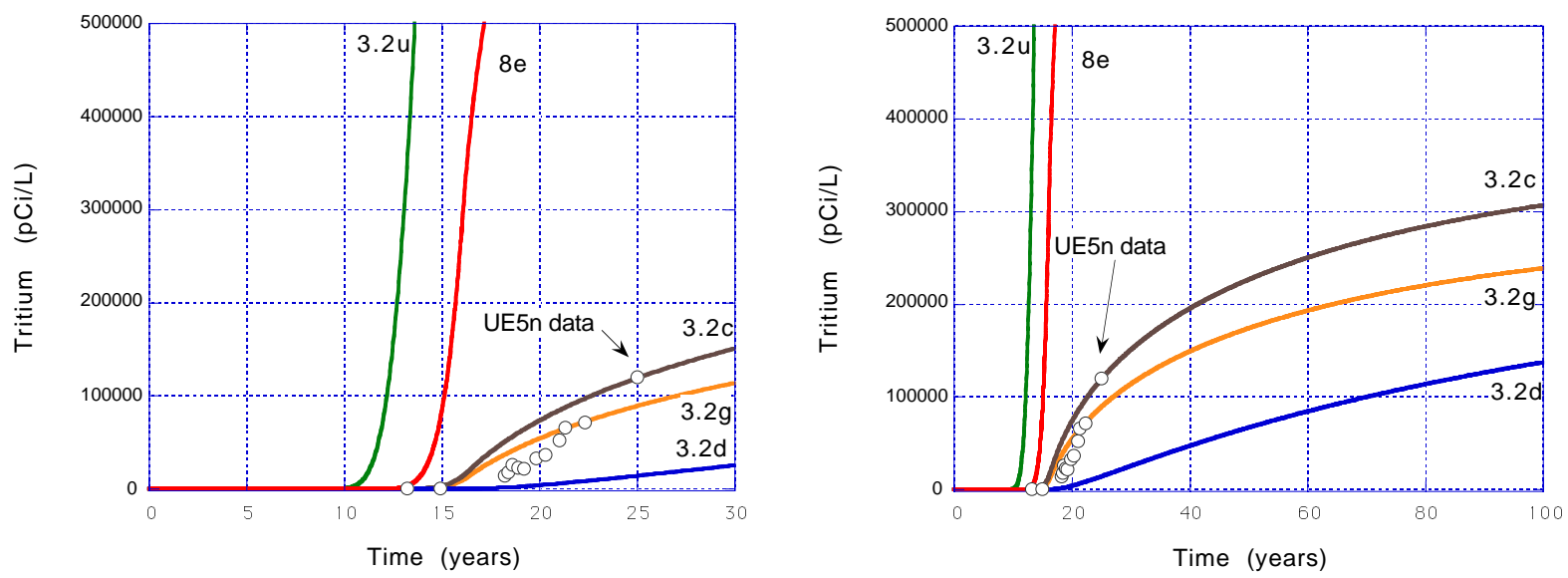

Figure 10. Predicted tritium concentrations in well UE5n from various simulations in Table 4, as compared with observations. Two different time scales are used. Time scale refers to years since initiation of pumping in 1975. 


\section{Run 3.2u}

25 years
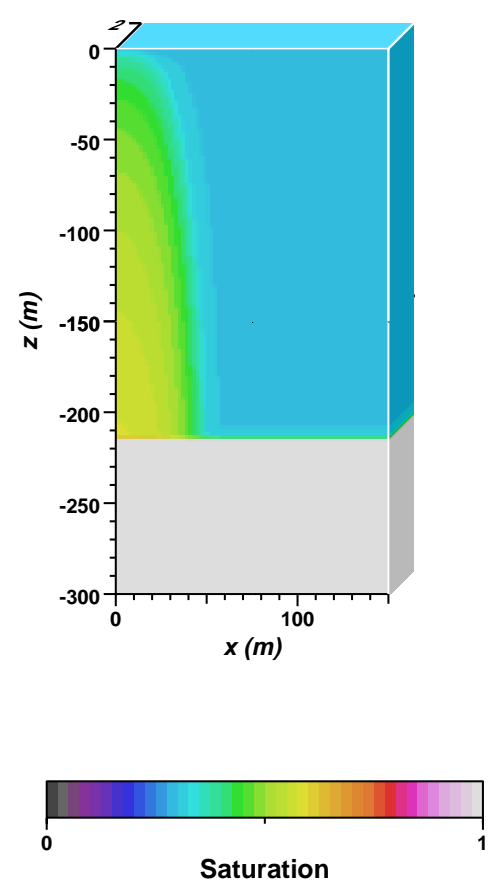

Run 3.2u

25 years

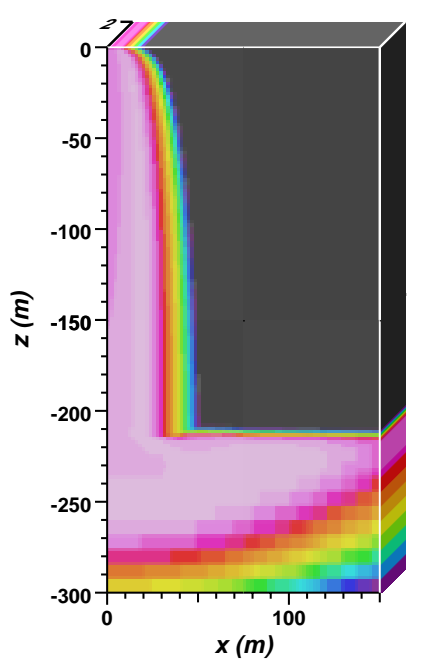

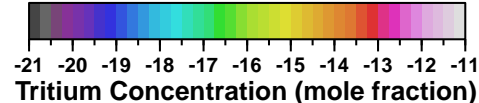

Figure 11. Saturation (left) and tritium concentration (right) profiles predicted from simulation 3.2u (Table 4) at 25 years after initiation of pumping. Monitoring Well UE5n is located at $x=106 \mathrm{~m}$.

As an alternative example, Figure 11 shows the saturation and tritium concentration of simulation $3.2 \mathrm{u}$ (Table 4 ) at $t=25$ years. This simulation involved slightly changed values of the $\alpha^{*}$ and $\mathrm{m}$ parameters. It resulted in slightly higher influx rates at the ditch (Figure 9), a broader and more dispersed residual plume of moisture in the vadose zone at 25 years (Figure 11 ), and a much more abrupt concentration profile at well UE5n (Figure 10).

Figure 10 also shows three other profiles obtained from three additional simulations listed in Table 4. Results from simulations 3.2c and 3.2d result again from slight variations in the $\alpha^{*}$ and $\mathrm{m}$ parameters. Simulation $8 \mathrm{e}$ results from slight variations in the permeability as well as the $\alpha^{*}$ and m parameters.

\section{New Chemical Measurements in the CAMBRIC System}

In addition to the simulation portion of this project, we also collected a suite of groundwater samples from wells RNM2s, UE5n, as well as the CAMBRIC cavity via drillback hole RNM1 (Figure 2). These samples were analyzed by mass spectrometry for tritium, ${ }^{3} \mathrm{He} /{ }^{4} \mathrm{He},{ }^{14} \mathrm{C}$, ${ }^{36} \mathrm{Cl} / \mathrm{Cl},{ }^{85} \mathrm{Kr}$ (by $\beta$-counting) ${ }^{99} \mathrm{Tc}$, and ${ }^{129} \mathrm{I}$, as well as for stable isotopes of $\mathrm{D} / \mathrm{H}$ and ${ }^{18} \mathrm{O} /{ }^{16} \mathrm{O}$ and augmented the historical measurements of tritium and ${ }^{36} \mathrm{Cl} / \mathrm{Cl}$ (see Bryant, 1992). The 
samples were not analyzed for ${ }^{106} \mathrm{Ru}$. We have also detected ${ }^{14} \mathrm{C}$ and ${ }^{85} \mathrm{Kr}$ in the original pumping well RNM2S, but not in UE5n (Finnegan and Thompson, 2001).

Many of the measured isotopes are soluble and serve as excellent tracers of groundwater flow. The tritium $/{ }^{3} \mathrm{He}$ ratio can be used as a barometer of age or travel time under saturated (below water table) conditions where the ${ }^{3} \mathrm{He}$ is constrained to remain in solution.

Measurements at the monitoring well UE5n suggest a tritium age of 9.5 years. Provided that it took approximately 13 to 15 years for the initial tritium discharged into the ditch to reach UE5n (see above), this suggests, in turn, a transit time through unsaturated conditions (i.e., the vadose zone) of 3.5 to 5.5 years. This result is in reasonable agreement with the transit time predicted by the simulations above, and again illustrates how age dating can be used as a new tool to provide finer calibration for the model (Tompson et al., 1999b).

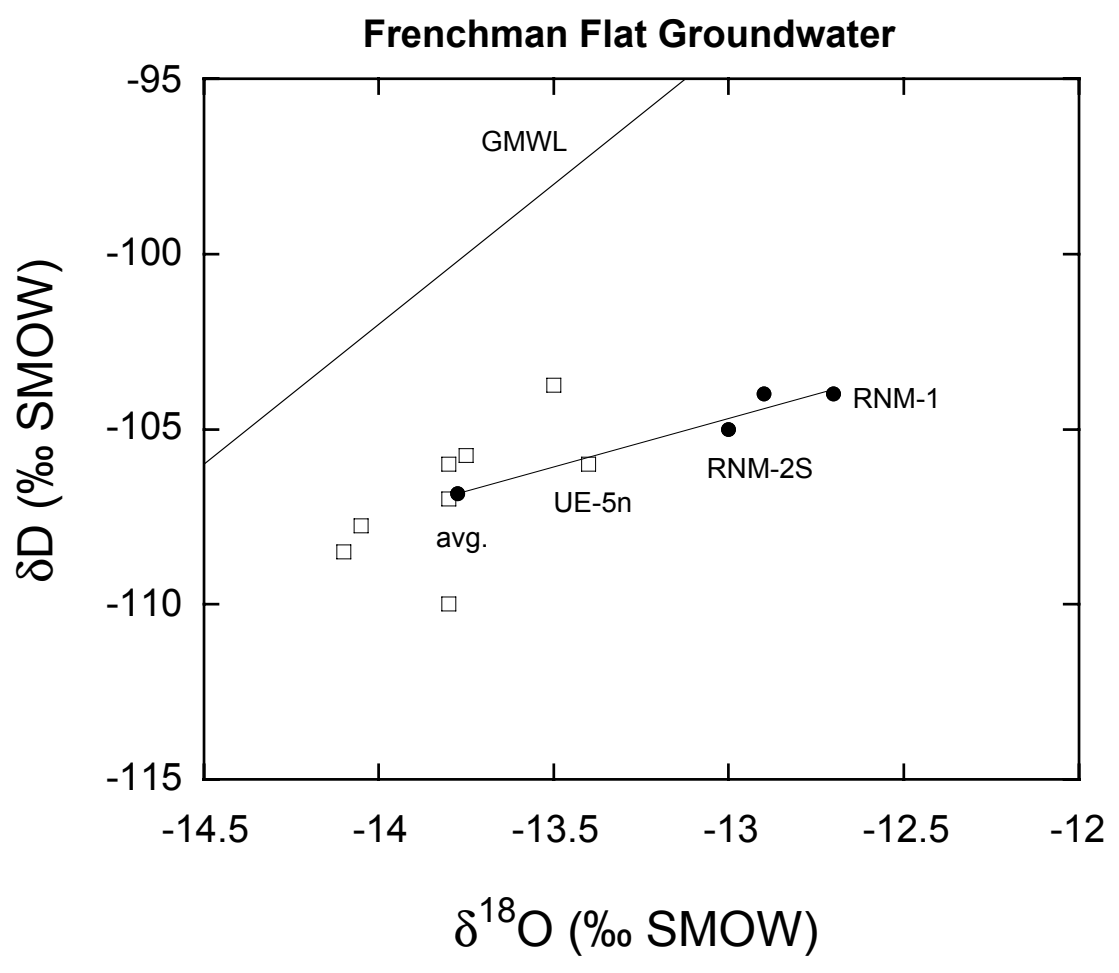

Figure 12. ${ }^{18} \mathrm{O} /{ }^{16} \mathrm{O}$ and $\mathrm{D} / \mathrm{H}$ data from recent measurements in RNM2S and RNM1 (closed circle on right) that show a increased degree of evaporation relative to other nearby Frenchman flat groundwater (open squares).

We have also applied the tritium age dating method to groundwater recently extracted (2000) from the original pumping well RNM2S. In principal, this water should represent the last groundwater drawn to the well over the 16-year pumping period, largely because hydraulic gradients in this area are so flat that groundwater would not be expected to move very far in the 9 years since pumping was stopped. Thus, the age of this water should reflect the time since the test - approximately 35 years. However, although the new tritium concentration was similar to 
the most recent value obtained in $1991(<2000 \mathrm{pCi} / \mathrm{ml}$; Figure 5), the calculated age turned out to be only 20 years.

A possible explanation for this was suggested by our simulations, namely, that tritium from the ditch was recycled back into the original pumping well. The "age" of recycled tritium, once it crosses the water table, will be zero (because accumulated ${ }^{3} \mathrm{He}$ partitions preferentially into the gas phase), so that its mixing with the "older" tritium will serve to reduce the "apparent age" of the groundwater. The gas loss is also corroborated by the loss of ${ }^{85} \mathrm{Kr}$ from the RNM2S pumping well to Ue5n. In turn, this suggests that 15 to $20 \%$ of the tritium (and other mobile radionuclides) pumped from the well over the 16 years was recycled and not wholly attributable to the nuclear test. The existence of recirculation is further supported by the data from the stable isotopes of ${ }^{18} \mathrm{O} /{ }^{16} \mathrm{O}$ and $\mathrm{D} / \mathrm{H}$ that clearly show an enrichments in the heavier isotope that accompanies evaporation during water recycling (Figure 12). This concept was originally discussed by Ross and Wheatcraft (1994), but never confidently confirmed with their simulations.

Detection of ${ }^{36} \mathrm{Cl},{ }^{99} \mathrm{Tc}$, and ${ }^{129} \mathrm{I}$ at the monitoring well UE5n indicates that these isotopes move in concert with tritium. However, the lack of ${ }^{14} \mathrm{C}$ in the monitoring well, despite its appearance in the pumping well RNM2S, suggests it was removed from water in the vadose zone, by isotopic exchange with common carbonate minerals.

\section{Conclusions and Recommendations}

\subsection{Conclusions}

Altogether, the current simulations and chemical observations suggest that the transport of tritium, ${ }^{36} \mathrm{Cl},{ }^{99} \mathrm{Tc}$, and ${ }^{129} \mathrm{I}$ through the $200 \mathrm{~m}$ vadose zone - under the ditch discharge conditions - is relatively fast ( 3 to 5 years). However, their residence-time in the draining system following the shutoff of the ditch appears to be much longer in comparison.

Contrary to original perceptions, the role of the vadose zone on radionuclide transport under the flowing conditions of the ditch - was non-trivial as evidenced by a significant return of mobile radionuclides to groundwater. With a few extensions (see below) the model can now be used to quantify the flux of radionuclides reaching the water table underneath the ditch, which is of considerable concern to environmental and waste disposal programs ongoing at the NTS. We also conclude from the current results that the presence of radionuclides in UE5n is entirely due to discharges from ditch, as opposed to transport in groundwater under ambient conditions from the nearby DILUTED WATERS or WISHBONE underground nuclear tests (Figures 3 and 4).

Furthermore, the long term nature of the experiment, the variety of chemical measurements and isotopic interpretations, and their incorporation into a unified modeling analysis have all contributed to a unique perspective for interpreting radionuclide migration. Because of the legacy of radioactive wastes identified in the surface or in the unsaturated zone at many sites in the DOE complex, our experience is important to accurate predictions of contaminant migration and remedial design in the vadose zone.

In particular, the model simulations and chemical age dating results determined in this study here are in approximate agreement with respect to travel times between the ditch and well 
UE5n. In addition, the existence of recirculation between the ditch and the pumping well will require a reevaluation of the original pump test data, as well as the myriad of models that have been applied to analyze radionuclide migration in the saturated zone between the CAMBRIC cavity and well RNM2S. These have all attributed the entirety of the pump test data as coming directly from the test cavity without the influence of any recirculation.

The vadose zone model results, although generally reasonable in many respects, were shown to be quite sensitive to the character and nature of the soil moisture and relative permeability relationships. This is, of course, typical of unsaturated flow models. The ability to match rising tritium levels in well UE5n with the model was also, most likely, exacerbated by the presence and impacts of geologic heterogeneity.

Notably, the transport of "reactive" radionuclides in the vadose zone could not be directly analyzed in this study because of their conspicuous absence in the RNM2S pumping well discharge. All of the radionuclides detected in RNM2S (tritium, ${ }^{3} \mathrm{He},\left({ }^{14} \mathrm{C},{ }^{36} \mathrm{Cl},{ }^{85} \mathrm{Kr},{ }^{129} \mathrm{I}\right.$, and

${ }^{106} \mathrm{Ru}$ ) were able to move there from the CAMBRIC cavity during the pumping experiment and were, thus, relatively mobile under saturated conditions. Relatively "immobile" species such as ${ }^{90} \mathrm{Sr},{ }^{137} \mathrm{Cs}$, and ${ }^{238.239} \mathrm{Pu}$ were detected in the cavity (RNM1) but not at the well (RNM2S) and were, thus, unavailable for discharge into the ditch. However, under unsaturated conditions, ${ }^{3} \mathrm{He}$, for example, is known to preferentially partition into the gas phase and will not move in water like a tracer, even though it will in the saturated zone. To a lesser extent, the same can be said for ${ }^{85} \mathrm{Kr}$. The relative mobility of tritium and ${ }^{36} \mathrm{Cl}$, albeit similar in a saturated environment, will differ in the vadose zone because tritium more readily evaporates into the gas phase. At the current location, this was first suggested by Buddemeier et al. (1991), and newer data at UE5n obtained in this study shows similar behavior. In addition, the transport of ${ }^{14} \mathrm{C}$ in the vadose zone and its apparent loss from the aqueous system suggesting its preferential retention, possibly due to precipitation or other isotopic exchange chemical reaction.

\subsection{Future Directions}

Based upon the current results, the following tasks are recommended for additional study :

- Develop a series of three-dimensional simulations to address and further quantify though a modeling perspective the recirculation of radionuclides to the pumping well (RNM2S) from the ditch;

- Complete an additional series of two-or three-dimensional simulations for all radionuclides that appeared in pumping effluent in order to quantify their return flux to groundwater. This will require some understanding of the recirculation behavior (previous bullet) as well as an understanding or approximation of the influx derived from that portion of the ditch flow discharged into the Frenchman Lake playa;

- Address, as possible with available information, the influence of geologic heterogeneity on the infiltration and radionuclide migration processes between the ditch and wells UE5n and RNM2s using a three-dimensional model;

- Complete a series of Lagrangian (or particle-based) simulations of tritium infiltration, in either a two-or three-dimensional sense, in order to examine additional details of the tritium age-dating technique, as used in the current saturated/unsaturated system; 
- Continue the collection of radionuclide concentration and related groundwater quality data in Well UE5n; and

- If possible, drill a new sampling borehole to the water table, preferably close to the ditch along a perpendicular line connecting well UE5n and the ditch, in order to collect alluvium samples for analysis of residual moisture, tritium, and other residual radionuclide content, such as ${ }^{14} \mathrm{C}$.

In addition, the ability of saltcedar shrubs surrounding the CAMBRIC ditch to bind tritium in their vascular tissue has recently been demonstrated by Prof. Jim Hunt and his students at UC Berkeley. The concentration of tritium in successive tree rings in the shrubs is nearly identical to the elution profile of tritium into the ditch from RNM-2S and may be exploited to quantify the transfer of infiltrated ditch water to the nearby vegetation (and its loss from the vadose zone).

\section{Acknowledgements}

The authors would like to thank Prof. Jim Hunt of U. C. Berkeley, Drs. Ken Rehfeldt and Mike Sully of Geotrans, Inc., and Drs. Steve Carle and Timothy Rose of LLNL for their cooperative discussions and supportive interest in this work. This work was performed under the auspices of the U. S. Department of Energy by the University of California, Lawrence Livermore National Laboratory under contract W-7405-ENG-48.

\section{References}

Anderson, J. E. (1977), Transpiration and photosynthesis in saltcedar. Hydrology and water resources in Arizona and the Southwest 7:125-131.

Blout, D. O., D. P. Hammermeister, K. A. Zukosky, and K. D. Donnelson (1995), Site characterization data from the Area 5 science boreholes, Nevada Test Site, Nye County, Nevada, Reynolds Electrical and Engineering Company, Inc., Las Vegas, NV (DOE/NV 11432-170/UC-721), $157 \mathrm{pp}$.

Brock, J. H. (1994), Tamarix spp. (Salt Cedar), and invasive exotic woody plant in arid and semi- arid riparian habitats of western USA, in Ecology and Management of Invasive Riverside Plants, L. C. de Waal, L. E. Child, P. M. Wade, and J. H. Brock, eds., Wiley \& Sons, New York.

Bodvarsson, G., S. Finsterle, H. H. Liu, C. Oldenburg, K. Pruess, E. Sonenthal, and Y-S Wu (2000), Flow and transport modeling of the vadose zone, in Vadose Zone Science and Technology Solutions, B. Looney and R. Falta, eds., Battelle Press, Columbus, 1540 pp.

Bryant, E. A. (1992) The CAMBRIC migration experiment: A summary report, Los Alamos National Laboratory, Los Alamos, NM (LA-12335-MS), 37pp. 
Burbey, T. J. and S. W. Wheatcraft (1986), tritium and chlorine-36 migration from a nuclear explosion cavity, Desert Research Institute, University of Nevada System, Reno, NV, (Publication 4505), 103 pp.

Buddemeier, R.W., R. C. Finkel, K. V. Marsh, M. R. Ruggieri, J. H. Rego, and R. J. Silva (1991) Hydrology and radionuclide migration at the Nevada Test Site, Radiochimica Acta, 52/53, 275-282.

Daniels, W. R., ed. (1982), Laboratory and field studies related to the radionuclide migration project, October 1, 1981-September 30, 1982, Los Alamos National Laboratory, Los Alamos, NM, LA-9691-PR.

Davisson, M . L., J. M. Kenneally, D. K. Smith, G. B. Hudson, G. J. Nimz, and J. H. Rego (1994), Preliminary report on the isotope hydrology investigations at the Nevada Test Site: hydrologic resources management program FY 1992-1993, Lawrence Livermore National Laboratory, Livermore, CA (UCRL-ID-116122), 90 pp.

Finnegan, D. L. and J. L. Thompson (2001), Laboratory and Field Studies Related to Radionuclide Migration at the Nevada Test Site in Support of the Underground Test Area Program and Hydrologic Resources Management Project, October 1, 1999 - September 30, 2000, Los Alamos National Laboratory (LA-13787-PR), 20pp.

Gay, L. W., T. W. Sammis, and J. Ben-Asher (1976), An energy budget analysis of evapotranspiration from saltcedar. Hydrology and water resources in Arizona and the southwest 7:133-139.

Guell, M.. A. (1997), Subsurface transport of radionuclides at the Nevada Test Site, PhD thesis, Department of Civil and Environmental Engineering, University of California, Berkeley, CA.

Hoffman, D. C., R. Stone, and W. W. Dudley, Jr. (1977), Radioactivity in the underground environment of the CAMBRIC nuclear explosion at the Nevada Test Site, Los Alamos National Laboratory, Los Alamos, NM (LA-6877-MS), 89 pp

IAEA (1998), The radiological situation at the atolls of Mururoa and Fangataufa. Technical report, Volume 4. Releases to the biosphere of radionuclides from underground nuclear weapons tests at the atolls. International Atomic Energy Agency, Vienna, Austria (IAEAMFTR-4).

Istok, J. D., D. O. Blout, L. Barker, K. R. Johnejack and D. P. Hammermeister (1994), Spatial variability in alluvium properties at a low level nuclear waste site, Soil Science Society of America Journal, 58,1040-1051.

LATA (Los Alamos Technical Associates) (1982), Selection of a simulation model for analysis of radionuclide migration at the RNM experiment site Nevada Test Site, Nevada, Los Alamos Technical Associates, Inc., Los Alamos, NM (LATA-LSL-29-01).

Mantoglou, A. and L. W. Gelhar (1987), Stochastic Modeling of large-scale transient unsaturated flow systems, Water Resources Research, 23, (1), 37-46.

Nitao, J. J. (1999), Users Manual for the USNT Module of the NUFT Code, Version 2.0.1 (NPphase. NC-component, thermal), Lawrence Livermore National Laboratory, Livermore, CA (UCRL-MA-130653-REV-1), 67 pp. 
Ogard, A. E., J. L. Thompson, R. S. Rundberg, K. Wolfsberg, P. W. Kubic, D. Elmore, and H. W. Bentley (1988), Migration of chlorine-36 and tritium from an underground nuclear test, Radiochimica Acta, 44/45, 213-217.

Ramspott, L. D., and R. D. McArthur (1977), Results of the exploratory drill hole UE5n, Frenchman Flat, Nevada Test Site, Lawrence Livermore National Laboratory, Livermore, CA (UCID-17392), 32pp.

REECO (Reynolds Electrical \& Engineering Co., Inc.) (1994), Site Characterization and Monitoring Data from Area 5 Pilot Wells, Nevada Test Site, Nye County, Nevada. U.S. Department of Energy (DOE/NV/11432-74).

Rose, T. P., R. I. Yamamoto, and G. F. Eaton, eds. (2002), Hydrologic Resources Management Program and Underground Test Area Project FY 2000 Progress Report, Lawrence Livermore National Laboratory, UCRL-ID-145167 (in preparation).

Ross, W. C. and S. W. Wheatcraft (1994), A two-dimensional simulation of tritium transport in the vadose zone at the Nevada Test Site, Desert Research Institute, Reno, NV (Publication No. 45098), 222 pp.

Tompson, A. F. B., C. J. Bruton, and G. A. Pawloski, eds. (1999a), Evaluation of the hydrologic source term from underground nuclear tests in Frenchman Flat at the Nevada Test Site: The CAMBRIC test, Lawrence Livermore National Laboratory, Livermore, CA (UCRL-ID132300), $355 \mathrm{pp}$.

Tompson, A. F. B., S. F. Carle, N. D. Rosenberg, and R. M. Maxwell (1999), Analysis of groundwater migration from artificial recharge in a large urban aquifer: A simulation perspective, Water Resources Research, 35(10), 2981-2998.

USDOE (1997), Regional groundwater flow and tritium transport modeling and risk assessment of the underground test area, Nevada Test Site, Nevada, U. S. Department of Energy, Nevada Operations Office, Environmental Restoration Division, Las Vegas, NV (DOE/NV$-477)$.

USDOE (2001), A National Roadmap for Vadose Zone Science and Technology:

Understanding, Monitoring, and Predicting Contaminant Fate and Transport in the Unsaturated Zone, U. S. Department of Energy, Idaho Operations Office, Idaho Falls, ID (DOE/ID 10871), 150 pp. 